\title{
HUBUNGAN FAKTOR MAINTENANCE TERHADAP KEPUASAN KERJA TENAGA MEDIS
}

Rokhmatul Hikmat*, Dasno**

\begin{abstract}
ABSTRAK
Faktor Maintenance adalah faktor-faktor pemeliharaan yang berhubungan dengan hakikat manusia yang ingin memperoleh ketentraman badaniah untuk memperoleh kepuasan. Penelitian ini bertujuan untuk mengetahui hubungan faktor maintenance terhadap kepuasan kerja tenaga medis di Rumah Sakit Pelabuhan Cirebon Tahun 2014. Metode yg digunakan deskriptif analitik dengan menggunakan desain penelitian cross sectional. Hal yang ingin diteliti adalah faktor maintenance diantaranya faktor gaji, kondisi kerja, kebijakan dan administrasi, hubungan teman kerja dan kualitas supervise terhadap kepuasan kerja tenaga medis di Rumah Sakit Pelabuhan Cirebon Tahun 2014. Metode yang digunakan dalam penelitian ini adalah deskriptif analitik dengan menggunakan desain penelitian cross sectional. Hal yang ingin diteliti adalah faktor maintenance diantaranya faktor gaji, kondisi kerja, kebijakan dan administrasi, hubungan denga teman kerja dan kualitas supervise terhadap kepuasan kerja tenaga medis di Rumah Sakit Pelabuhan Cirebon tahun 2014. Populasi penelitian ini adalah tenaga medis yang bekerja di Rumah Sakit Pelabuhan Cirebon sebanyak 40, dengan jummlah sampel yang diambil adalah total populasi. Pengumpulan data dilakukan dengan wawancara menggunakan kuesioner. Pengolahan dan analisa data dilakukan dengan menggunakan program SPSS. Analisa bivariat menggunakan uji chi square. Hasil penelitian menunjukkan bahwa yanga mempersepsikan kepuasan kerja yang tidak puas sebanyak 55\%. Dari hasil uji statistic (Uji Chi Square) didapatkan bahwa variabel yang berhubungan secara bermakna terhadap kepuasan adalah faktor gaji $(\mathrm{P}-$ value $=0,043)$, kondisi kerja $(\mathrm{P}-$ value $=0,015)$, kebijakan dan administrasi $(\mathrm{P}$ value $=0,021)$, hubungan teman kerja $(\mathrm{P}$-value $=0,033)$ dan variabel yang tidak berhubungan adalah faktor kualitas supervisi (P-value $=1,000)$.
\end{abstract}

Kata Kunci $\quad$ : Faktor Maintenance dan Kepuasan Kerja

\begin{abstract}
Maintenance factors are factors related to the maintenance of human nature that wants to obtain peace corporal to obtain satisfaction. This study aims to determine the relationship maintenance factors on job satisfaction of medical personnel in Cirebon Harbor Hospital in 2014. The method used in this research is descriptive analytical cross-sectional research design. Things to meticulous maintenance factors including factors are salary, working conditions, policies and administration, co-worker relationships, and the quality of supervision on job satisfaction of medical personnel in Cirebon Harbor Hospital in 2014. The population of this research is that medical personnel working at Harbor Hospital in Cirebon, as many as 40, the number of samples taken is the total population. The data was collected using a questionnaire interview. Processing and data analysis performed using SPSS. Bivariate analysis using Chi - Squaretest in order to see the relationship between two variables, independent and dependent.The results showed that respondents who perceive job satisfaction and satisfied as much as $45 \%$ of respondents who perceive job satisfaction is not satisfied as much as $55 \%$. From the results of statistical tests (Chi - Square Test) found that there was a significant relationship variables on job satisfaction is the salary factor $(P$ - value $=0.043)$, working conditions $(P-$ value $=0.016)$, and administrative policies $(P$ value $=0.021)$, coworker relationships $(P-$ value $=0.033)$ and asministrative policies $(\mathrm{p}$-value $=0,021)$, coworker relationship ( $\mathrm{p}$-value $=0,033$ ) and a variable that no significant relationship was supervising the quality factor (Pvalue $=1,000)$
\end{abstract}

Keywords : : Maintenance Factors and Job Satisfaction

\footnotetext{
* Staf Pengajar Program Studi S1 Keperawatan STIKes Cirebon

**Alumni PSKM STIKes Cirebon Lulus Tahun 2014
} 


\section{PENDAHULUAN}

Rumah sakit sebagai suatu organisasi akan terus berubah sesuai dengan pertumbuhan dan pengaruh lingkungannya, sehingga untuk dapat bertahan dan berkembang dalam lingkungan yang berubah cepat, paradigma menejemen rumah sakit harus diubah menjadi efektif, efisien dan mempunyai kemampuan untuk mengakomodasi perubahan. ${ }^{1}$

Kunci sukses kegiatan pelayanan rumah sakit terletak kepada para dokter sebagai pemberi pelayanan di rumah sakit. Dari sudut manajemen, para dokter merupakan pelanggan rumah sakit. Dalam posisi demikian, manajemen organisasi tetap mempunyai bargaining power yang kuat karena beberapa alasan dokter lebih menyukai bentuk kerja sama hospital based group, karena adanya job security (jaminan keamanan dalam bekerja) bentuk pelayanan yang sudah mempunyai jangkauan pasar pelayanan,sarana yang lengkap dan siap pakai. Dalam hal ini hubungan yang baik dan sistem yang kondusif akan menjembatani dokter dengan rumah sakit. ${ }^{1}$

Diungkapkan pula oleh Massie dalam Aditama ${ }^{1}$, bahwa dokter sebagai profesional sangat mempengaruhi pelayanan di rumah sakit. Biasanya profesional tersebut cenderung otonom dan berdiri sendiri, bahkan tak jarang misinya tidak sejalan dengan manajemen rumah sakit. Dalam hal ini, manajer rumah sakit harus mampu mengintegrasikan kemandirian profesional dokter ke dalam keseluruhan visi - misi rumah sakit yang sudah ditetapkan.

Pelayanan medik khususnya medik spesialistik merupakan salah satu ciri dari rumah sakit yang membedakan rumah sakit dengan fasilitas pelayanan lainnya. Kontribusi pelayanan medik pada pelayanan di rumah sakit cukup besar dan menentukan ditinjau dari berbagai aspek, antara lain aspek jenis pelayanan, aspek keuangan, pemasaran, etika dan hukum maupun administrasi dan menejemen rumah sakit itu sendiri. ${ }^{2}$

Kinerja Medik Rumah sakit Pelabuhan Cirebon, selama periode semester I tahun 2013 berhasil mencapai kunjungan pasien sebanyak 106.911 orang atau 3,51\% masih dibawah target rencana kerja anggaran perusahaan (RKAP). sedangkan Bed Occupancy Rate (BOR) rata - rata sebesar $68,38 \%$ atau $2,90 \%$ diatas target.

Tabel 1 Pencapaian target kunjungan

\begin{tabular}{|c|c|c|c|c|c|c|c|}
\hline \multirow{2}{*}{ No } & \multirow{2}{*}{ Unit Pelayanan } & \multirow{2}{*}{ Satuan } & \multirow{2}{*}{$\begin{array}{l}\text { Realisasi } \\
\text { Smt } 2012\end{array}$} & \multirow{2}{*}{$\begin{array}{c}\text { RKAP Smt } \\
2013\end{array}$} & \multirow{2}{*}{$\begin{array}{c}\text { Realisasi Smt } \\
2013\end{array}$} & \multirow{2}{*}{$\begin{array}{c}\text { Deviasi } \\
\%\end{array}$} & \multirow{2}{*}{$\begin{array}{c}\text { Trend } \\
\%\end{array}$} \\
\hline & & & & & & & \\
\hline 1 & Rawat Jalan & Orang & 18,867 & 21,849 & 20,426 & -6.51 & 108.26 \\
\hline 2 & Kamar Operasi & Orang & 533 & 641 & 476 & -25.74 & 89.37 \\
\hline 3 & ICU & Orang & 327 & 374 & 334 & -10.70 & 102.14 \\
\hline 4 & IGD & Orang & 6,428 & 7,500 & 7,158 & -4.56 & 111.36 \\
\hline
\end{tabular}

Dari data laporan medik Rumah sakit Pelabuhan Cirebon semester 1 tahun 2013 mengenai realisasi kegiatan operasional tentang pencapaian target kunjungan didapat kunjungan secara umum masih dibawah target RKAP :

1. Realisasi kunjungan rawat jalan semester satu ,pencapaian target tidak tercapai.

2. Realisasi kunjungan kamar operasi,pencapaian target tidak tercapai.

3. Realisasi kunjungan ICU, pencapaian target tidak tercapai.

4. Realisasi kunjungan instalasi gawat darurat, pencapaian target tidak tercapai.

Kinerja karyawan mempengaruhi kinerja organisasi, apabila kinerja karyawan rendah mengakibatkan kinerja Rumah sakit rendah karena tenaga medis merupakan profesi yang 
berhubungan langsung dengan pasien dan merupakan karyawan yang memiliki waktu yang lebih lama berinteraksi dengan pasien disaat melakukan pelayanan dibandingkan dengan karyawan lain, mengakibatkan kinerja tenaga medis berpengaruh besar terhadap kinerja Rumah sakit. $^{3}$

Muchlas menyatakan bahwa kinerja organisasi dipengaruhi oleh kinerja individu sementara kinerja individu dipengaruhi oleh kepuasan kerja individu, sehingga kinerja pelayanan pasien di Rumah sakit Pelabuhan Cirebon dipengaruhi oleh kinerja tenaga medis sementara kinerja tenaga medis akan tinggi apabila pada saat melakukan pekerjaannya tenaga medis memiliki rasa nyaman. Rasa nyaman disaat melaksanakan pekerjaan akan tercapai apabila tenaga medis memperoleh kepuasan kerja. ${ }^{3}$

Kepuasan kerja adalah keadaan emosional yang menyenangkan atau sikap umum terhadap perbedaan penghargaan yang diterima dan yang seharusnya diterima serta terhadap faktor-faktor pekerjaan, penyesuaian diri dan hubungan sosial individu di luar kerja. ${ }^{4}$

Herzberg mengatakan bahwa orang dalam melaksanakan pekerjaannya dipengaruhi oleh dua faktor yang merupakan kebutuhan, yaitu maintenance faktor adalah faktor-faktor pemeliharaan yang berhubungan dengan hakekat manusia yang ingin memperoleh ketentraman badaniah, antara lain 1) gaji, 2) kondisi kerja, 3) kebijakan dan administrasi perusahaan, 4) hubungan antar pribadi/ teman sekerja, 5) kualitas supervisi dan motivation faktor adalah faktor-faktor yang menyangkut kebutuhan psikologis seseorang, antara lain: (1) prestasi, (2) pengakuan, (3) pekerjaan itu sendiri, (4) tanggungjawab, (5) pengembangan potensi diri. $^{5}$

Tujuan penelitian ini ntuk mengetahui hubungan faktor maintenance (gaji, kondisi kerja, kebijakan dan administrasi, hubungan dengan teman sekerja dan kualitas supervisi) terhadap kepuasan kerja tenaga medis di Rumah Sakit Pelabuhan Cirebon tahun 2014.

\section{METODE PENELITIAN}

Jenis penelitian yang digunakan dalam penelitian ini adalah penelitian deskriptif korelasi, ${ }^{6}$ Penelitian ini menggunakan pendekatan atau rancangan adalah rancangan cross sectional atau potong lintang ${ }^{7}$ Populasi dalam penelitian ini adalah seluruh tenaga medis yang ada dan praktek di Rumah Sakit Pelabuhan Cirebon tahun 2014, sejumlah 40 orang. Sampel dalam penelitian ini adalah total populasi sejumlah 40 orang/ tenaga medis.

Teknik pengumpulan data ini menggunakan data primer meliputi data karakteristik (jenis kelamin, departemen, unit kerja, jenjang pangkat, lama kerja, dan pendidikan) dan data faktor maintenance (faktor gaji, kondisi kerja, kebijakan dan administrasi perusahaan, hubungan teman sekerja dan kualitas supervisi) dan kepuasan kerja tenaga medis diperoleh melalui wawancara. Instrument yang digunakan berupa kuesioner.

Analisa data dengan analisis Univariat disajikan dalam bentuk tabel dan analisa persentase. Sedangkan analisis bivariat ditujukan untuk melihat hubungan variabel independen yaitu faktor maintenance yang meliputi faktor gaji, kondisi kerja, kebijakan dan administrasi perusahaan, hubungan teman sekerja dan kualitas supervise dengan variabel dependen yaitu tingkat kepuasan tenaga medis. Analisis bivariat ini dilakukan melalui uji statistik Chi-Square. Untuk melihat hasil kemaknaan perhitungan statistik digunakan batas kemaknaan $\alpha=0,05$

\section{HASIL PENELITIAN}

\section{Faktor gaji}

Tenaga medis yang mempersepsikan faktor gaji rendah sebanyak 17 orang $(42.5 \%)$. Sedangkan tenaga medis yang mempersepsikan faktor gaji tinggi yaitu sebanyak 23 orang $(57.5 \%)$. 


\section{Kondisi kerja}

Tenaga medis yang mempersepsikan kondisi kerja kurang baik yaitu sebanyak 16 orang (40\%). Sedangkan Tenaga medis yang mempersepsikan kondisi kerja baik sebanyak 24 orang $(60 \%)$.

\section{Kebijakan dan Administrasi}

Tenaga medis yang mempersepsikan kebijakan dan administrasi kurang baik yaitu sebanyak 18 orang $(45 \%)$. Sedangkan tenaga medis yang mempersepsikan kebijakan dan administrasi baik 22 orang (55\%).

\section{Hubungan Teman Kerja}

Tenaga medis yang mempersepsikan hubungan teman kerja kurang baik yaitu sebanyak 15 orang $(37,5 \%)$. Sedangkan tenaga medis yang mempersepsikan hubungan teman kerja baik 25 orang $(62,5 \%)$.

\section{Kualitas Supervisi}

Tenaga medis yang mempersepsikan kualitas supervisi kurang baik yaitu sebanyak 23 orang $(57,5 \%)$. Sedangkan tenaga medis yang mempersepsikan kualitas supervisi baik 17 orang $(42,5 \%)$.

\section{Kepuasan Kerja}

Tenaga medis yang menyatakan kurang puas dalam bekerja sebanyak 22 orang (55\%). Sedangkan tenaga medis yang menyatakan puas dalam bekerja sebanyak 18 orang (45\%).

\section{Hubungan faktor gaji terhadap kepuasan kerja tenaga medis}

Tabel 1. Hubungan faktor gaji terhadap kepuasan kerja tenaga medis

\begin{tabular}{|c|c|c|c|c|c|c|c|}
\hline \multirow{3}{*}{ Faktor gaji } & \multicolumn{4}{|c|}{ Kepuasan kerja } & \multirow{2}{*}{\multicolumn{2}{|c|}{ Total }} & \multirow{3}{*}{$\mathrm{P}$ value } \\
\hline & \multicolumn{2}{|c|}{ Kurang Puas } & \multicolumn{2}{|c|}{ Puas } & & & \\
\hline & $\mathrm{n}$ & $\%$ & $\mathrm{n}$ & $\%$ & $\mathrm{~N}$ & $\%$ & \\
\hline Rendah & 13 & 76,5 & 4 & 23,5 & 17 & 100 & \\
\hline Tinggi & 9 & 31,1 & 14 & 60,9 & 23 & 100 & \\
\hline Total & 22 & 55 & 18 & 45 & 40 & 100 & \\
\hline
\end{tabular}

Dari kedua proporsi tersebut menunjukkan $\mathrm{P}=0,043(\mathrm{p} \leq \alpha)$ yang berarti ada hubungan yang bermakna antara faktor gaji terhadap kepuasan kerja pada tenaga medis di Rumah Sakit Pelabuhan Cirebon tahun 2014. 


\section{Hubungan kondisi kerja terhadap kepuasan kerja tenaga medis}

Tabel 2 Hubungan kondisi kerja terhadap kepuasan kerja tenaga medis

\begin{tabular}{|c|c|c|c|c|c|c|c|}
\hline \multirow{3}{*}{ Kondisi kerja } & \multicolumn{4}{|c|}{ Kepuasan kerja } & \multirow{2}{*}{\multicolumn{2}{|c|}{ Total }} & \multirow{3}{*}{$\mathrm{P}$ value } \\
\hline & \multicolumn{2}{|c|}{ Kurang Puas } & \multicolumn{2}{|c|}{ Puas } & & & \\
\hline & $\mathrm{n}$ & $\%$ & $\mathrm{n}$ & $\%$ & $\mathrm{~N}$ & $\%$ & \\
\hline Kurang Baik & 13 & 81,2 & 3 & 18,8 & 16 & 100 & \\
\hline Baik & 9 & 37,5 & 15 & 62,5 & 24 & 100 & 0,016 \\
\hline Total & 22 & 55 & 18 & 45 & 40 & 100 & \\
\hline
\end{tabular}

Dari kedua proporsi tersebut menunjukkan $\mathrm{P}=0,016(\mathrm{p} \leq \alpha)$ yang berarti ada hubungan yang bermakna antara kondisi kerja dengan kepuasan kerja pada tenaga medis.

\section{Hubungan kebijakan dan administrasi terhadap kepuasan kerja tenaga medis}

Tabel 3 Hubungan kebijakan dan administrasi terhadap kepuasan kerja tenaga medis

\begin{tabular}{|c|c|c|c|c|c|c|c|}
\hline \multirow{3}{*}{$\begin{array}{c}\text { Kebijakan dan } \\
\text { administrasi }\end{array}$} & \multicolumn{4}{|c|}{ Kepuasan kerja } & \multirow{2}{*}{\multicolumn{2}{|c|}{ Total }} & \multirow{3}{*}{$\mathrm{P}$ value } \\
\hline & \multicolumn{2}{|c|}{ Kurang Puas } & \multicolumn{2}{|c|}{ Puas } & & & \\
\hline & $\mathrm{n}$ & $\%$ & $\mathrm{n}$ & $\%$ & $\mathrm{~N}$ & $\%$ & \\
\hline Kurang Baik & 14 & 77,8 & 4 & 22,2 & 18 & 100 & \\
\hline Baik & 8 & 36,4 & 14 & 63,6 & 22 & 100 & \\
\hline Total & 18 & 55 & 22 & 45 & 40 & 100 & \\
\hline
\end{tabular}

Dari kedua proporsi tersebut menunjukkan $P=0,021(p \leq \alpha)$ yang berarti ada hubungan yang bermakna antara kebijakan dan administrasi terhadap kepuasan kerja pada tenaga medis.

Hubungan hubungan teman kerja terhadap kepuasan kerja tenaga medis

Tabel 4 Hubungan hubungan teman kerja terhadap kepuasan kerja tenaga Medis

\begin{tabular}{|c|c|c|c|c|c|c|c|}
\hline \multirow{3}{*}{$\begin{array}{l}\text { Hubungan } \\
\text { teman kerja }\end{array}$} & \multicolumn{4}{|c|}{ Kepuasan kerja } & \multirow{2}{*}{\multicolumn{2}{|c|}{ Total }} & \multirow{3}{*}{$\mathrm{P}$ value } \\
\hline & \multicolumn{2}{|c|}{ Kurang Puas } & \multicolumn{2}{|c|}{ Puas } & & & \\
\hline & $\mathrm{n}$ & $\%$ & $\mathrm{n}$ & $\%$ & $\mathrm{n}$ & $\%$ & \\
\hline Kurang Baik & 12 & 80 & 3 & 20 & 15 & 100 & 0,033 \\
\hline Baik & 10 & 40 & 15 & 60 & 25 & 100 & \\
\hline
\end{tabular}




\begin{tabular}{lllllll}
\hline Total & 22 & 55 & 18 & 45 & 40 & 100
\end{tabular}

Dari kedua proporsi tersebut menunjukkan $\mathrm{P}=0,033(\mathrm{p} \leq \alpha)$ yang berarti ada hubungan yang bermakna antara hubungan teman kerja terhadap kepuasan kerja pada tenaga medis.

\section{Hubungan kualitas supervisi terhadap kepuasan kerja tenaga medis}

Tabel 5.11 Hubungan kualitas supervisi terhadap kepuasan kerja tenaga medis

\begin{tabular}{|c|c|c|c|c|c|c|c|}
\hline \multirow{3}{*}{$\begin{array}{l}\text { Kualitas } \\
\text { supervisi }\end{array}$} & \multicolumn{4}{|c|}{ Kepuasan kerja } & \multirow{2}{*}{\multicolumn{2}{|c|}{ Total }} & \multirow{3}{*}{$P$ value } \\
\hline & \multicolumn{2}{|c|}{ Kurang Puas } & \multicolumn{2}{|c|}{ Puas } & & & \\
\hline & $\mathrm{N}$ & $\%$ & $\mathrm{n}$ & $\%$ & $\mathrm{n}$ & $\%$ & \\
\hline Kurang Baik & 12 & 52,2 & 11 & 47,8 & 23 & 100 & \multirow{3}{*}{0,923} \\
\hline Baik & 10 & 28,8 & 7 & 41,2 & 17 & 100 & \\
\hline Total & 22 & 55 & 18 & 45 & 40 & 100 & \\
\hline
\end{tabular}

Dari kedua proporsi tersebut menunjukkan $\mathrm{P}=0,923(\mathrm{p} \geq \alpha)$ yang berarti tidak ada hubungan yang bermakna antara kualitas supervisi terhadap kepuasan kerja pada tenaga medis di rumah sakit pelabuhan Cirebon tahun 2014.

\section{PEMBAHASAN}

\section{Hubungan faktor gaji terhadap kepuasan kerja tenaga medis}

Hasil penelitian menunjukkan bahwa ada hubungan yang bermakna antara hubungan faktor gaji terhadap kepuasan kerja pada tenaga medis di Rumah Sakit Pelabuhan Cirebon Tahun 2014.

Pada dasarnya seseorang yang bekerja mengharapkan gaji atau imbalan yang sesuai dengan jenis pekerjaannya, karena adanya insentif yang sesuai dengan pekerjaannya, maka akan timbul pula rasa gairah kerja semakin baik. Imbalan dari bekerja banyak bentuknya dan tidak selalu tergantung pada uang. Gaji atau imbalan adalah hal - hal yang mendorong tenaga kerja untuk bekerja lebih giat, hal ini sesuai dengan penelitian yang dilakukan oleh Akustia eni dan Susi nurhayati bahwa faktor gaji atau insentif mempengaruhi kepuasan kerja responden. ${ }^{8}$

\section{Hubungan kondisi kerja terhadap kepuasan kerja tenaga medis}

Hasil penelitian menunjukkan bahwa ada hubungan yang bermakna antara hubungan kondisi kerja terhadap kepuasan kerja pada tenaga medis di Rumah Sakit Pelabuhan Cirebon Tahun 2014.

Hal ini sesuai dengan prinsip dari teori Equity yaitu seseorang akan merasa puas atau tidak puas tergantung pada apakah pekerjaan tersebut merasakan adanya suatu keadilan atau tidak atas suatu kondisi/situasi kerja. Perasaan puas atau tidak puas dari seseorang diperoleh dengan cara membandingkan dirinya dengan orang lain dalam suatu organisasinya sendiri atau dibandingkan dengan individu lain yang sejenis didalam organisasi yang lain.Seperti penelitian oleh Akustia eny bahwa kondisi/situasi kerja responden mempengaruhi kepuasan kerja. $^{8}$

Faktor kondisi kerja merupakan salah satu faktor lain yang mampu mempengaruhi kepuasan kerja karyawan. Kondisi kerja yang baik dalam arti sempit adalah lokasi yang aman, 
nyaman, bersih dan tenang, peralatan baik dan modern. ${ }^{9}$ Kondisi kerja yang menyenangkan akan menjadi kunci pendorong bagi para karyawan untuk menghasilkan kinerja puncak.

\section{Hubungan kebijakan dan administrasi terhadap kepuasan kerja tenaga medis}

Hasil penelitian menunjukkan bahwa ada hubungan yang bermakna antara hubungan kebijakan dan administrasi terhadap kepuasan kerja. Kebijakan dan administrasi yang baik dan adil akan dirasakan oleh tenaga medis / karyawan sehingga mempengaruhi kepuasan kerja mempengaruhi produktivitas kerja karyawan, dengan demikian untuk meningkatkan produktivitas kerja karyawan perlu memperhatikan kepuasan kerja karyawan.

Tenaga medis atau karyawan berusaha mendapatkan kebijakan dan administrasi dari praktek manajemen yang adil, sebagaimana contoh promosi memberikan kesempatan untuk pertumbuhan pribadi, tanggung jawab yang lebih banyak dan status sosial ditingkatkan. Oleh karena itu individu - individu yang mempersepsikan bahwa keputusan dan kebijakan promosi di buat dengan cara adil (fair and just) kemungkinan besar akan mengalami kepuasan dari pekerjaan mereka. ${ }^{8}$

\section{Hubungan hubungan teman kerja terhadap kepuasan kerja tenaga medis}

Hasil penelitian menunjukkan bahwa ada hubungan yang bermakna antara hubungan hubungan teman kerja terhadap kepuasan kerja pada tenaga medis. Pendapat Gibson et al (1996) menyatakan bahwa dukungan social dari rekan sekerja diperlukan bagi setiap karyawan. Rekan sekerja yang menciptakan situasi bersahabat dan mendukung akan menimbulkan kepuasan kerja karyawan. Kepuasan yang didapat dari rekan sekerja bisa berupa perasaan yang dihargai. ${ }^{8}$

Keterkaitan teman kerja dengan kepuasan kerja meliputi teman kerja yang dapat memotivasi pekerjaan, menyenangkan, cepat menyelesaikan pekerjaan, sangat tanggap, perhatian dan loyal terhadap institusi serta jujur dan tanggung jawab. Komunikasi antar teman kerja mempengaruhi sikap seseorang terhadap pekerjaannya.

\section{Hubungan kualitas supervisi terhadap kepuasan kerja tenaga medis}

Dari hasil penelitian bahwa ada hubungan yang bermakna antara hubungan kualitas supervisi terhadap kepuasan kerja pada tenaga medis. Tidak adanya hubungan yang bermakna antara kualitas supervisi terhadap kepuasan kerja tenaga medis di RS Pelabuhan Cirebon, dimungkinkan karena responden sebagian besar hampir $45 \%$ merupakan tenaga medis RS pada klinik spesialis sehingga mereka beranggapan tidak ada supervisi, padahal supervisinya adalah ketua komite medik yang telah disepakati bersama. Oleh karena kinerja komite medik tidak terlihat secara jelas oleh tenaga medis spesialis serta kurangnya koordinasi antara dokter spesialis dengan komite medik. Serta dalam melaksanakan supervisi komite medik dan manajemen tidak menggunakan instrumen yang baku atau tolok ukur yang akan dipakai untuk supervisi kepada tenaga medis.

\section{SIMPULAN}

1. Ada hubungan yang bermakna antara faktor gaji terhadap kepuasan kerja pada tenaga medis

2. Ada hubungan yang bermakna antara kondisi kerja terhadap kepuasan kerja pada tenaga medis.

3. Ada hubungan yang bermakna antara kebijakan dan administrasi terhadap kepuasan kerja pada tenaga medis.

4. Ada hubungan yang bermakna antara hubungan teman kerja terhadap kepuasan kerja pada tenaga medis. 
5. Tidak ada hubungan yang bermakna antara kualitas supervise terhadap kepuasan kerja pada tenaga medis.

\section{SARAN}

\section{Bagi Rumah Sakit Pelabuhan Cirebon}

1) Untuk meningkatkan kepuasan kerja tenaga medis faktor gaji dengan perubahan sistem pengelolaan gaji/insentif yang dapat diterima oleh semua pihak.

2) Untuk meningkatkan kepuasan kerja tenaga medis faktor kondisi kerja dengan cara peningkatan jumlah dan kualitas alat-alat kerja yang dibutuhkan oleh tenaga medis sesuai perkembangan IPTEK.

3) Untuk meningkatkan kepuasan kerja tenaga medis faktor kebijakan dan administrasi perusahaan dengan membuat dan merancang kebijakan dan administrasi sesuai dengan kepentingan dan harapan serta perlunya dilakukan silang pendapat dengan tenaga medik serta dibuat kebijakan dan prosedur klinis maupun non medis sesuai standar.

4) Untuk meningkatkan kepuasan kerja tenaga medis faktor hubungan teman sekerja:

(1) Pembentukan Tim Kerja dalam komite medik dan Re-organisasi komite medik

(2) Mengaktifkan morning report sebagai wadah untuk menampung aspirasi dan masukan dari tenaga medis terutama dokter spesialis serta pihak manajemen selalu hadir dalam morning report.

\section{Bagi tenaga medis.}

1) Bekerja secara profesional dan menjalankan proses pelayanan kedokteran yang ramah, peduli dan bersahabat kepada pelanggan rumah sakit.

2) Melaksanakan tindakan pengobatan secara ikhlas dalam bekerja pada saat melayani pasien maupun pelanggan rumah sakit sesuai dengan hati nurani dan kode etik profesi kedokteran.

\section{DAFTAR PUSTAKA}

1. Aditama, TY. Manejemen Administrasi Rumah Sakit. Jakarta:UI-Press;2002.

2. Direktorat Rumah Sakit Umum dan Pendidikan Dirjen Yanmed DepKes RI. Standar Pelayanan Rumah Sakit. Cetakan Ketiga, Jakarta;1994.

3. Muchlas, M. Perilaku Organisasi. Program Pendidikan Pasca Sarjana Magister Manajemen Rumah Sakit. Universitas Gajah Mada. Yogyakarta;1997.

4. Gito Sudarmo. dkk. Perilaku Keorganisasian . Edisi pertama. Cetakan pertama. Yogyakarta: BPFE;1997.

5. Robbins. Stephen P. Perilaku Organisasi, Konsep Kontroversi - Aplikasi. Edisi Bahasa Indonesia, Jilid 1. Jakarta: PT Prenhallindo;1996.

6. Azwar, S. Metode Penelitian Kuantitatif Kualitatif dan R \& D. Bandung: Alfabeta;2009

7. Aziz Alimul. Metode penelitian kesehatan paradigm kuantitatif, Health books publishing. Cetakan kedua. Surabaya: HBP;2011.

8. Akustia Eny. Pengaruh karakteristik dan faktor kondisi pekerjaan dengan kepuasan kerja perawat puskesmas di kabupaten Pati [Tesis]. Semarang.Undip;2001

9. Pandji Anogara. Psikologi Kerja. Cetakan kelima. Jakarta: Rineke cipta;2009. 